\title{
INTRODUCTION TO THE SYMPOSIUM ON THE OLYMPICS AND INTERNATIONAL LAW
}

\author{
Laurence Boisson de Chazournes*
}

The intersection between international law and the Olympic Games is hardly explored at all, although the potential encounters are many and varied. In light of the forthcoming 2021 Olympic Games (rescheduled from 2020 due to the Covid pandemic), this symposium analyzes the contemporary legal questions triggered by the Olympics and examines what the application of international law in this unique setting reveals. As such, it aims to fill the gap in the literature on the international legal issues that emerge from the convergence of thousands of athletes from a wide range of states at a single sporting event—and one that is privately ordered.

Various bodies of law are involved in one manner or another in this particular set of circumstances. The legal status of the norms in question vary depending on whether we are referring to principles of international law, to non-binding instruments, to secondary law adopted within the framework of multilateral conventions, to national laws or to contracts. The six essays that make up this symposium illustrate these various normative facets through selected themes. The themes include the notion of citizenship and how athletes use their talents to obtain citizenship, state recognition, and Olympic participation, the way in which the Olympics brings contemporary human rights and environmental challenges to the forefront and the legal instruments that are resorted to for promoting their respect. Moreover, the efficacy and normative contours of the self-regulating private legal order that is the Olympics deserve attention.

The governance of the Olympic Games is often characterized by pragmatism. The initiatives taken with respect to dispute settlement offer a revealing example. In this context, due to the specific organizational requirements of the Olympic Games, special procedures designed to settle disputes within a very short timeframe were needed. A dedicated structure within the Court of Arbitration for Sport—functioning in situ—was first established in 1996 and has existed since then for each edition of the Olympic Games. ${ }^{1}$ In 2016, an additional division dealing with anti-doping disputes was created. The need for efficiency and speed resulted in succinct and clear rules of procedure for these dispute mechanisms. ${ }^{2}$

Human rights and environmental protection concerns have also prompted legal initiatives. As a reaction to increasing pressure from civil society to address adverse human rights impacts during the Olympic Games, the International Olympic Committee (IOC) has promoted the inclusion of human rights provisions into the bidding process and hosting regulations for the Olympic Games. Daniela Heerdt from Tilburg Law School writes about the costs and benefits of embedding such human rights concepts in these bidding and hosting agreements. ${ }^{3}$ She reveals that, from a rights-holder perspective, the benefits are in fact rather meaningless. Her analysis sheds light

* Professor of International Law, University of Geneva, Switzerland.

${ }^{1}$ Laurence Boisson de Chazournes \& Ségolène Couturier, The Court of Arbitration for Sport for the XXIII Olympic Games, 22(3) ASIL INSIGHTS (2018).

2 Arbitration Rules Applicable to the CAS Ad Hoc Division for the Olympic Games, COURT OF Arbitration For Sport.

${ }^{3}$ Daniela Heerdt, A Rights-Holder View on Human Rights Provisions in Olympic Bidding and Hosting Regulations, 114 AJIL UnBOUnd 356 (2020).

(C) Laurence Boisson de Chazournes 2020. This is an Open Access article, distributed under the terms of the Creative Commons 354 Attribution licence (http://creativecommons.org/licenses/by/4.0/), which permits unrestricted re-use, distribution, and reproduction in any medium, provided the original work is properly cited. 
on how the potential benefits are cancelled out by the shortcomings. In a different way, climate change has led the Olympic authorities to launch initiatives that seek to address this global challenge. In her essay, Rebecca Schmidt from the University of Oslo examines the Olympic Movement's multi-level climate change policy. ${ }^{4}$ In the context of the Olympic Games, this policy is implemented through the interplay between the IOC and actors at the local, host city level. The system is thus highly dependent on local organizers' capabilities, as well as on the IOC's willingness and ability to take an active role in steering and supporting host cities in this process.

Identity and citizenship have always been associated with the Olympics and various points of view have been expressed on these issues. James Nafziger from Willamette University College of Law writes on the mutuality of national and international identity in international sports law. ${ }^{5} \mathrm{He}$ assesses whether the term "national" should be defined by national laws with all of their variations and uncertainties, by a concept of sport nationality, or by both criteria, and if a genuine link should exist between a national and the country of the National Olympic Committee. In a globalized world, he calls for greater clarity on the necessary mutuality between national and international identities in fulfilling the spirit of friendship, solidarity, and fair play in the practice of sport. Peter Spiro from Temple University discusses the idea of abandoning nationality requirements for the Olympics. ${ }^{6}$ He considers that nationality and associated criteria for participant eligibility undermine the autonomy of athletes and the quality of participation and that the rules can no longer guarantee any effective tie between athletes and nations. To the extent that athletes want to compete for other countries, Olympic rules shouldn't stand in the way. Another issue concerning identity is related to statehood. Interestingly, some entities that are not yet states have been able to participate in the Olympic Games. In this context, Ryan Gauthier from Thompson Rivers University examines the connection between participation in the Olympic Games and claims to statehood. ${ }^{7}$ He considers sport's role through the modern approach to statehood and looks in particular at two examples: the German Democratic Republic and Kosovo.

The Olympic Movement has been self-regulated from the outset, and its private ordering is governed by the domestic law of the countries in which its organizations are domiciled and operate. It is also, however, an institution of global governance with links to international law. Doriane Lambelet Coleman from Duke Law School writes about the claim that the Olympic Movement and its subsidiaries should be more closely tied to international law. ${ }^{8}$ She examines the nature of those ties and the push for additional alignment between the norms of the Movement and international legal norms. She argues that, while regulatory autonomy is necessary for sport to produce the values expected by its stakeholders, domestic law as it reflects international law is generally an adequate check on abuses of that autonomy. She considers that international norms are useful not as binding law that would displace the Movement's autonomy, but as pressure for the Movement's organizations to consider aligning their policies and procedures with the public interests those norms reflect, such as, for example, human dignity.

\footnotetext{
${ }^{4}$ Rebecca Schmidt, The Carbon Footprint of the Games - International Climate Change Law and the Olympics, 114 AJIL UnBOUND 362 (2020).

${ }^{5}$ James A.R. Nafziger, The Mutuality of National and International Identities in International Sports Law, 114 AJIL UnBound 368 (2020).

${ }^{6}$ Peter J. Spiro, Problematizing Olympic Nationality, 114 AJIL Unbound 374 (2020).

${ }^{7}$ Ryan Gauthier, Statehood and the Olympic Games, 114 AJIL Unbound 380 (2020).

${ }^{8}$ Doriane Lambelet Coleman, The Olympic Movement in International Law, 114 AJIL UnBound 385 (2020).
} 